\title{
IMPLEMENTASI FRAMEWORK CODEIGNTER UNTUK PENGEMBANGAN WEBSITE PADA DINAS PERKEBUNAN PROVINSI KALIMANTAN TENGAH
}

\author{
Rio Irawan ${ }^{1}$, Sulistyowati ${ }^{2}$ \\ Sekolah Tinggi Manajemen Informatika dan Komputer (STMIK) Palangka Raya \\ Jl. G.Obos No.114, Palangka Raya 73112 Indonesia \\ E-mail: 1210irawan@gmail.com ${ }^{1}$, sty.kireina@yahoo.com ${ }^{2}$
}

\begin{abstract}
ABSCTACT
Implementation Framwork CodeIgniter at Plantation Office of Central Kalimantan Province aims to deliver profile information, commodity prices, business partners, announcements, official agenda, gallery activities as well as downloaded files. Method used in this study includes data collection methods (literature review, interviews) and methods of analysis, namely data analysis and systems analysis. The analysis system used is PIECES analysis.

With this website visitor facilities in seeking information about the price of commodities, the announcement and the agenda of the services, download files plantations and can see photos and video activities Plantation Office of Central Kalimantan Province and features that allow visitors to be more efficient in finding the necessary information and features more than the previous blogspot media.
\end{abstract}

Keywords: Plantation Office of Central Kalimantan Province, Website, Framewok Codeigniter

\section{PENDAHULUAN}

Perkembangan teknologi saat ini sudah mengalami kemajuan yang sangat pesat, salah satunya adalah internet. Manfaat internet saat ini sangat dirasakan masyarakat dan bahkan sudah menjadi kebutuhan, segala informasi dapat dengan mudah di dapatkan di internet selama ada koneksi. Langkah awal munculnya teknologi internet ini membuat beberapa subyek untuk membangun. Penggunaan website sebagai salah satu media sarana komunikasi sudah sedemikian luasnya dengan faktor biaya yang murah, kemudahan akses dan efisiensi karena dapat diakses dalam waktu 24 jam. Teknologi website mengalami perkembangan yang cukup pesat. Website saat ini bukan hanya merupakan media informasi yang sekedar di baca atau cenderung statis, tetapi telah 
berkembang menjadi media yang lebih dinamis dan interaktif.

Dinas Perkebunan Provinsi Kalimantan Tengah adalah salah satu bagian dari berbagai dinas yang ada di Provinsi Kalimantan Tengah. Dinas Perkebunan Provinsi Kalimantan Tengah memiliki banyak bagian yang tugas nya secara langsung berkaitan dengan pelayanan kepada masyarakat baik itu petani maupun perusahaan yang bekerja sama dengan dinas perkebunan.

Dalam proses bisnisnya Dinas Perkebunan Provinsi Kalimantan Tengah memiliki tugas yang berkaitan dengan perkebunan seperti kelapa sawit, karet, lada dan komoditas lainnya. Pada saat ini Dinas Perkebunan Provinsi Kalimantan Tengah dalam menyampaikan informasi kepada masyarakat masih menggunakan media blogspot sehingga informasi yang ingin disampaikan masih banyak kendala, untuk itu diperlukan sebuah media website agar dapat memberikan informasi yang lebih lengkap kepada masyarakat. Dinas Perkebunan Provinsi Kalimantan Tengah sendiri juga termasuk salah satu SKPD yang belum memiliki website, karena setiap SKPD diwajibkan memiliki sebuah website untuk menyampaikan informasi yang dimilikinya sehingga SKPD lain atau masyarakat luas bisa mendapatkan informasi dari Dinas Perkebunan Provinsi Kalimantan Tengah.

\section{KAJIAN TEORI}

\section{Framework CodeIgniter}

Menurut Basuki

(2014:12)

Framework adalah paket berisi fungsi-fungsi yang biasa digunakan dalam pembuatan aplikasi. Beberapa contoh fungsi standar yang biasa ada sebuah Framework misalnya : email, paging, kalender, tanggal, bahasa, upload file, session, validasi form, Tabel, manipulasi Gambar, text, string, captcha, enkripsi, proteksi terhadap XSS, security dan lain-lain. Fungsi-fungsi tersebut dapat segera digunakan dengan cara memanggilnya pada program, tentu saja cara memanggilnya tergantung dari Framework yang digunakan. Jadi, Programmer tidak perlu membuat lagi fungsi-fungsi tersebut dari awal. Metode yang digunakan oleh Framework CodeIgniter disebut Model View-Controller atau yang disingkat dengan sebutan MVC. MVC memisahkan antara logika pemrograman dengan presentasi. Hal ini dapat terlihat dari adanya minimalisir script presentasi (HTML, CSS, JavaScript, dan sebagainya) yang dipisahkan dari PHP 
(Hypertext Preprocessor) script. Didalam folder CodeIgniter, $M V C$ dapat kita temukan dalam folder application. CodeIgniter juga menjadi salah satu Framework pilihan yang memungkinkan developer untuk membuat sebuah aplikasi web dengan karakter pengembangan RAD ( Rapid Application Development ), yang memungkinkan untuk digunakan dan dikembangkan menjadi aplikasi lain yang lebih kompleks. CodeIgniter terdiri dari file-file pustaka ( library ), kelas-kelas, dan infrastruktur runtime yang terinspirasi oleh Framework Ruby on Rails.

\section{Analisis PIECES}

Metode PIECES digunakan untuk menganalisa kinerja informasi, ekonomi, keamanan aplikasi, efisiensi, dan pelayanan pelangganan. Analisa PIECES dibagi menjadi:

\section{Performance}

Performance atau Analisis kinerja adalah permasalahan kinerja ketika tugas - tugas bisnis yang dijalankan tidak mencapai sasaran. Kinerja diukur dengan jumlah produksi dan waktu tanggap. Jumlah produksi adalah jumlah pekerjaan yang bisa diselesaikan selama jangka waktu tertentu. Pada bagian pemasaran kinerja diukur berdasarkan volume pekerjaan, pangsa pasar yang diraih, atau citra perusahaan.

\section{Information}

Analisis informasi dilakuakan terhadap kemampuan sistem informasi dan menghasilkan informasi yang bermanfaat perlu dilakukan untuk menyikapi peluang dan menangani masalah yang muncul. Permasalahan yang biasa dihadapi meliputi:

a. Data yang berlebihan. Data yang sama ditangkap dan atau disimpan di banyak tempat

b. Kelakuan data. Data ditangkap dan disimpan, tetapi diorganisasikan sedemikian rupa sehingga laporan dan pengujian tidak dapat atau sulit dilakukan 


\section{Economy}

Analisis Ekonomi merupakan motivasi paling umum bagi suatu proyek. Pijakan dasar bagi kebanyakan manajer adalah biaya atau rupiah. Persoalan ekonomis dan peluang berkaitan dengan masalah biaya . Adapun hal-hal yang perlu diperhatikan dapat disimak berikut:

a. Biaya

1) Biaya tidak diketahui

2) Biaya tidak dapat dilacak ke sumber.

3) Biaya terlalu tinggi

b. Keuntungan Control

1) Pasar- pasar baru dapat dieksplorasi

2) Pemasaran saat ini dapat diperbaiki

3) Pesanan- pesanan dapat ditingkatkan

\section{Eficiency}

Analisis efisiensi menyangkut bagaimana menghasilkan output yang sebayakbanyaknya dengan input yang sekecil mungkin. Berikut adalah indikasi bahwa suatu sistem dapat dikatakan tidak efisien:

a. Banyak waktu yang terbuang pada aktivitas sumber daya manusia, mesin, atau komputer.

b. Data diinput atau disalin secara berlebihan

c. Data diproses secara berlebihan.

d. Informasi dihasilkan secara berlebihan.

e. Usaha yang dibutuhkan untuk tugastugas terlalu berlebihan.

f. Material yang dibutuhkan untuk tugastugas terlalu berlebihan.

\section{Services}

Berikut adalah beberapa kriteria penilaian dimana kualitas suatu sistem bisa dikatakan buruk:

a. Sistem menghasilkan produk yang tidak akurat.

b. Sistem menghasilkan produk yang tidak konsisten. 
c. Sistem menghasilkan produk yang tidak dipercaya.

c. Sistem tidak mudah dipelajari.

d. Sistem tidak mudah digunakan.

e. Sistem canggung untuk digunakan.

f. Sistem tidak fleksibel

Dari analisis ini biasanya didapatkan beberapa masalah utama. Hal ini penting karena biasanya yang muncul di permukaan bukan masalah utama, tetapi hanya gejala dari masalah utama saja. (Fatta, 2007: 51 54)

\section{Unified Modelling Language (UML)}

UML (Unified Modelling Language) adalah 'bahasa' pemodelan untuk sistem atau perangkat lunak yang berparadigma 'berorientasi objek'. Pemodelan (modeling) sesungguhnya digunakan untuk penyerderhanaan permasalahan-permasalah yang kompleks sedemekian rupa sehingga lebih mudah dipelajari dan dipahami Menurut Nugroho (2010:6).
Menurut Sholiq (2006:6) Notasi UML dibuat sebagai kolaborasi dari Grady Booch, DR.James Rumbough, Ivar Jacobson, Rebecca Wirfs-Brock, Peter Yourdon, dan lainnya. Penggabungan beberapa metode menjadi UML dimulai 1993, setiap orang dari tiga sekawan dirational mulai mengabungkan idenya dengan metodemetode lainnya. Pada akhir tahun 1995 Unified Method diperbaiki dan diubah menjadi UML pada tahun 1996, UML 1.0 disahkan dan diberikan pada Object Technology Group (OTG) pada tahun 1997, dan pada tahun itu juga beberapa perusahaan pengembang utama perangkat lunak mulai mengadopsinya. Pada tahun yang sama OMG merilis UML 1.1 sebagai standar industri.

\section{PHP: Hypertext Preprocessor (PHP)}

Menurut Kadir (2008:2) PHP merupakan singkatan dari Hypertext Preprocessor. Ia merupakan bahasa berbentuk script yang ditempatkan dalam server dan diproses 
diserver. Hasilnya yang dikirm ke klien, tempat pemakai menggunakan browser.

Secara khusus, PHP (Hypertext Preprocessor) dirancang untuk membentuk aplikasi web dinamis. Artinya, ia dapat membentuk suatu tampilan berdasarkan permintaan terkini. Misalnya, anda bisa menampilkan isi database ke halaman web. Pada prinsipnya PHP (Hypertext Preprocessor ) mempunyai fungsi yang sama dengan script-script seperti ASP (Active Server Page), cold fusion, ataupun perl. Namun, perlu diketahui PHP sebenarnya bias dipakai secara command line artinya, script PHP (Hypertext Preprocessor) dapat dijalankan tanpa melibatkan web server maupun browser seperti yang dijelaskan pada Gambar 1 .

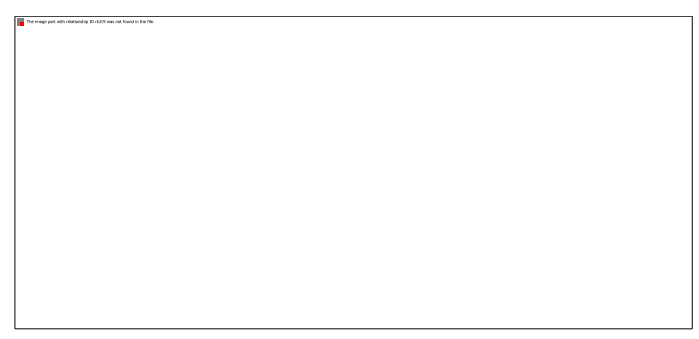

Gambar 1. Skema PHP

MySQL
Menurut Arief (2011:151) MySQL dikembangkan oleh sebuah perusahaan Swedia bernama MySQLAB yang pada saat itu bernama TcXDataKonsult AB sekitar tahun 1994-1995, namun cikal bakal kodenya sudah ada sejak 1979. Awalnya TcX membuat MySWL dengan tujuan pengembangan aplikasi web untuk klien. TcX merupakan perusahaan pengembang software dan konsultan database. Saat ini MySQL sudah diakuisisi oleh Oracle Corp. MySQL salah satu jenis database server yang sangat terkenal dan banyak digunakan untuk membangun aplikasi web yang menggunakan database sebagai sumber dan pengelolaan datanya. Kepoluleran $M y S Q L$ antara lain karena mysql menggunakan SQL sebagai bahasa dasar untuk mengakses database-nya sehingga mudah untuk digunakan, kinerja query cepat, dan mencakupi untuk kebutuhan database perusahaan-perusahaan skala menengah hingga yang kecil. $M y S Q L$ juga bersifat 
open source dan free (anda tidak perlu

membayar untuk menggunakannya).

Terdapat 3 jenis perintah SQL, yaitu

DDL,DML, dan DCL.

\section{Data Definition Language (DDL)}

DDL merupakan perintah SQL yang berhubungan dengan pendefinisian suatu struktur database, dalam hal ini database dan Tabel. Beberapa perintah dasar yang termasuk DDL ini antara lain CREATE, ALTER, DROP.

\section{Data Manipulation Language (DML)}

DML merupakan perintah SQL yang berhubungan dengan manipulasi atau pengolahan data atau record dalam Tabel. Perintah SQL yang termasuk dalam DML antara lain SELECT, INSERT, UPDATE, DELETE.

\section{Data Control Language (DCL)}

Merupakan perintah SQL yang berhubungan dengan pengaturan hak akses User MySQL, baik terhadap server, database, tabel maupun field. Perintah SQL yang termasuk dalam DCL antara lain : GRANT, REVOKE.

\section{ANALISIS}

\section{Analisis Kelemahan Sistem}

Dari hasil analisa yang telah dilakukan adalah menggunakan analisis PIECES sehingga diperoleh data seperti Tabel 1.

Tabel 1. Analisis Kelamahan Sistem

\begin{tabular}{|c|c|c|}
\hline $\begin{array}{c}\text { Jenis } \\
\text { Analisis }\end{array}$ & Sistem Lama & $\begin{array}{c}\text { Sistem yang } \\
\text { diajukan }\end{array}$ \\
\hline 1 & 2 & 3 \\
\hline $\begin{array}{c}\text { Analisis } \\
\text { Kinerja } \\
\text { (Performance } \\
\text { ) }\end{array}$ & $\begin{array}{ll}\text { - Jumlah } \\
\text { informasi } \\
\text { yang } \\
\text { mampu } \\
\text { disampaika } \\
\text { n terbatas } \\
\text { karena } \\
\text { hanya } \\
\text { menggunak } \\
\text { an fasilitas } \\
\text { yang ada } \\
\text { diblog. } \\
\end{array}$ & $\begin{array}{ll}\text { - Jumlah } \\
\text { informasi } \\
\text { yang } \\
\text { disampaika } \\
\text { n bisa lebih } \\
\text { optimal } \\
\text { sesuai apa } \\
\text { yang ingin } \\
\text { disampaika } \\
\text { n ke } \\
\text { masyarakat } \\
\text { luas. } \\
\end{array}$ \\
\hline $\begin{array}{c}\text { Analisis } \\
\text { Informasi } \\
\text { (Information) }\end{array}$ & $\begin{array}{l}\text { - Penyampaia } \\
\mathrm{n} \text { informasi } \\
\text { yang } \\
\text { disampaikan } \\
\text { kurang } \\
\text { menyeluruh } \\
\text { sehingga } \\
\text { informasi } \\
\text { yang } \\
\text { disampaikan } \\
\text { belum bisa } \\
\text { maksimal }\end{array}$ & $\begin{array}{l}\text { - Penyampaia } \\
\mathrm{n} \text { informasi } \\
\text { yang } \\
\text { disampaikan } \\
\text { lebih } \\
\text { banyak dan } \\
\text { bisa } \\
\text { bervariasi } \\
\text { sehingga } \\
\text { yang } \\
\text { informasi } \\
\text { ingin } \\
\text { disampaikan } \\
\text { bisa } \\
\text { menyeluruh. }\end{array}$ \\
\hline $\begin{array}{l}\text { Analisis } \\
\text { Ekonomi } \\
\text { (Economy) }\end{array}$ & $\begin{array}{l}\text { - Biaya gratis } \\
\text { tetapi } \\
\text { fasilitas } \\
\text { yang } \\
\text { didapat } \\
\text { tidak bisa } \\
\text { sesuai yang } \\
\text { diinginkan }\end{array}$ & $\begin{array}{l}\text { - Biaya tidak } \\
\text { gratis } \\
\text { karena } \\
\text { memerluka } \\
\text { n server } \\
\text { untuk } \\
\text { meletakkan } \\
\text { file website } \\
\text { dan biaya } \\
\text { perawatan } \\
\text { websitenya. }\end{array}$ \\
\hline
\end{tabular}




\begin{tabular}{|c|c|c|}
\hline $\begin{array}{l}\text { Analisis } \\
\text { Kendali } \\
(\text { Control })\end{array}$ & $\begin{array}{l}\text { Tidak bisa } \\
\text { diupgrade } \\
\text { fasilitas } \\
\text { nya . }\end{array}$ & $\begin{array}{l}\text { - Fasilitas bisa } \\
\text { ditambah } \\
\text { sesuai } \\
\text { kebutuhan } \\
\text { karena } \\
\text { Website } \\
\text { menggunaka } \\
\text { n Framework } \\
\text { codeigniter } \\
\text { yang } \\
\text { memudahkan } \\
\text { dalam } \\
\text { pengembang } \\
\text { anya. }\end{array}$ \\
\hline $\begin{array}{c}\text { Analisis } \\
\text { Efisiensi } \\
\text { (Effeciency) }\end{array}$ & $\begin{array}{l}\text { Kurang } \\
\text { efisien } \\
\text { karena pada } \\
\text { setiap SKPD } \\
\text { diharuskan } \\
\text { memiliki } \\
\text { sebuah } \\
\text { website } \\
\text { bukan blog. } \\
\text { Dan fasilitas } \\
\text { yang dimiliki } \\
\text { tidak bisa di } \\
\text { tambah. }\end{array}$ & $\begin{array}{l}\text { - Lebih } \\
\text { effisien } \\
\text { karena } \\
\text { website bisa } \\
\text { di tambah } \\
\text { fasilitas nya } \\
\text { sehingga } \\
\text { memudahkan } \\
\text { admin dan } \\
\text { petugas } \\
\text { dalam } \\
\text { memberikan } \\
\text { informasi ke } \\
\text { masyarakat }\end{array}$ \\
\hline $\begin{array}{l}\text { Analisis } \\
\text { Layanan } \\
(\text { Service })\end{array}$ & $\begin{array}{l}\text { Pelayanan } \\
\text { tidak bisa } \\
\text { maksimal } \\
\text { karena bila } \\
\text { menggunak } \\
\text { an blog } \\
\text {,admin } \\
\text { hanya bisa } \\
\text { memberika } \\
\text { n informasi } \\
\text { yang } \\
\text { sedikit. }\end{array}$ & $\begin{array}{l}\text { Pelayanan } \\
\text { lebih baik } \\
\text { karena } \\
\text { informasi } \\
\text { yang } \\
\text { diberikan } \\
\text { bisa lebih } \\
\text { banyak dan } \\
\text { bervariasi } \\
\text { sehingga } \\
\text { masyarakat } \\
\text { merasa puas. }\end{array}$ \\
\hline
\end{tabular}

\section{DESAIN SISTEM}

\section{Use Case Diagram}

Pada case ini user akan melakukan pencarian informasi, melihat berita, melihat pengumuman dan agenda, melihat galeri dan foto serta dapat mengunduh file yang ada di sistem informasi perkebunan sedangkan admin melakukan pengelolaan data informasi, data berita, data agenda dan pengumuman, data foto dan video dan data file yang akan di upload. Seperrti pada Gambar 2.

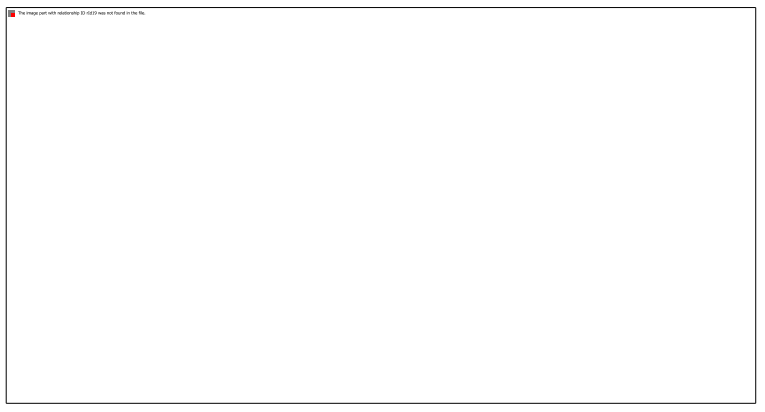

Gambar 2. Use Case Diagram

\section{Rancangan Basis Data}

a. Tabel Administrator

Tabel 2. Tabel Administrator

\begin{tabular}{|l|l|l|}
\hline Field & Tipe Data & Size \\
\hline Username & Varchar & 25 \\
\hline Password & Varchar & 25 \\
\hline
\end{tabular}

b. Tabel Agenda

Tabel 3. Tabel Administrator

\begin{tabular}{|l|l|l|}
\hline Field & Tipe Data & Size \\
\hline Id_agenda & Integer & 5 \\
\hline Tema_agenda & Varchar & 200 \\
\hline Isi & Text & \\
\hline tgl_mulai & Date & \\
\hline tgl_selesai & Date & \\
\hline tgl_posting & Date & \\
\hline Tempat & Varchar & 150 \\
\hline Jam & Varchar & 50 \\
\hline Keterangan & Tinytext & \\
\hline
\end{tabular}

c. Tabel Berita

Tabel 4. Tabel Berita

\begin{tabular}{|l|l|l|}
\hline Field & Tipe Data & Size \\
\hline Id_berita & Integer & 3 \\
\hline
\end{tabular}




\begin{tabular}{|l|l|l|}
\hline Id_komentar & Ineteger & 3 \\
\hline judul_berita & Varchar & 100 \\
\hline Isi & Text & \\
\hline Gambar & Varchar & 100 \\
\hline Tanggal & Date & \\
\hline Waktu & Time & \\
\hline Author & Integer & 10 \\
\hline Counter & Integer & 3 \\
\hline
\end{tabular}

d. Tabel Data

h. Tabel Menu

Tabel 9. Tabel Menu

\begin{tabular}{|l|l|l|}
\hline Field & Tipe Data & Size \\
\hline Id & Char & 10 \\
\hline Title & Varchar & 50 \\
\hline Id_parent & Char & 10 \\
\hline Level & Integer & 11 \\
\hline
\end{tabular}

i. Tabel Pengumuman

Tabel 10. Tabel Pengumuman

\begin{tabular}{|l|l|l|}
\hline Field & Tipe Data & Size \\
\hline Id_data & Integer & 11 \\
\hline Content & Text & \\
\hline data_id & Varchar & 10 \\
\hline
\end{tabular}

e. Tabel Download

Tabel 6. Tabel Download

\begin{tabular}{|l|l|l|}
\hline Field & Tipe Data & Size \\
\hline id_Download & Integer & 5 \\
\hline judul_file & Varchar & 200 \\
\hline nama_file & Varchar & 200 \\
\hline tgl_posting & Date & \\
\hline Author & Integer & \\
\hline
\end{tabular}

f. Tabel Galeri

Tabel 7. Tabel Galeri

\begin{tabular}{|l|l|l|}
\hline Field & Tipe Data & Size \\
\hline id_foto & Integer & 5 \\
\hline id_album & Integer & 10 \\
\hline foto_kecil & Varchar & 25 \\
\hline foto_besar & Varchar & 25 \\
\hline
\end{tabular}

g. Tabel Album Galeri

Tabel 8. Album Galeri

\begin{tabular}{|l|l|l|}
\hline Field & Tipe Data & Size \\
\hline Id_album & Integer & 5 \\
\hline Nama_album & Varchar & 25 \\
\hline
\end{tabular}

j. Tabel Pesan

Tabel 11. Tabel Pesan

\begin{tabular}{|l|l|l|}
\hline Field & Tipe Data & Size \\
\hline id_pesan & Integer & 11 \\
\hline Nama & Varchar & 100 \\
\hline Email & Varchar & 150 \\
\hline Pesan & Text & \\
\hline Status & Char & 5 \\
\hline tgl_posting & Datetime & \\
\hline
\end{tabular}

\section{Entitiy Relationship Diagram (ERD)}

Didalam perencanaan desain basis data diperlukan Entitiy Relationship Diagram (ERD) untuk memudahkan dalam membuat dan memahami struktur tabel dalam basis data. 


\begin{tabular}{|c|c|c|c|}
\hline $\begin{array}{c}\text { Data } \\
\text { Masukan }\end{array}$ & $\begin{array}{c}\text { Yang } \\
\text { Diharap- } \\
\text { kan }\end{array}$ & $\begin{array}{c}\text { Pengamat } \\
\text { an }\end{array}$ & $\begin{array}{c}\text { Kesimpul } \\
\text { an }\end{array}$ \\
\hline $\begin{array}{l}\text { Menjalank } \\
\text { an website } \\
\text { mengguna } \\
\text { kan } \\
\text { Firefox } \\
\text { Mozilla } \\
41.0 .2\end{array}$ & $\begin{array}{l}\text { Website } \\
\text { dapat } \\
\text { berjalan } \\
\text { dengan } \\
\text { baik }\end{array}$ & $\begin{array}{l}\text { Webiste } \\
\text { dapat } \\
\text { berjalan } \\
\text { dengan } \\
\text { baik }\end{array}$ & Diterima \\
\hline $\begin{array}{l}\text { Menjalank } \\
\text { an Website } \\
\text { Mengguna } \\
\text { kan } \\
\text { Google } \\
\text { Chrome } \\
\text { Versi } \\
48.0 .2535 . \\
0\end{array}$ & $\begin{array}{c}\text { Website } \\
\text { dapat } \\
\text { berjalan } \\
\text { dengan } \\
\text { baik }\end{array}$ & $\begin{array}{c}\text { Website } \\
\text { dapat } \\
\text { berjalan } \\
\text { dengan } \\
\text { baik }\end{array}$ & Diterima \\
\hline $\begin{array}{l}\text { Menjalank } \\
\text { an Website } \\
\text { Mengguna } \\
\text { kan } \\
\text { Internet } \\
\text { Explorer } \\
8.0 .7600 .1 \\
6385\end{array}$ & $\begin{array}{l}\text { Website } \\
\text { dapat } \\
\text { berjalan } \\
\text { dengan } \\
\text { baik }\end{array}$ & $\begin{array}{c}\text { Website } \\
\text { dapat } \\
\text { berjalan } \\
\text { dengan } \\
\text { baik }\end{array}$ & Diterima \\
\hline
\end{tabular}

\section{PEMBAHASAN}

\section{Rencana Pengujian Sistem}

Tabel 12. Rencana Pengujian Sistem

\section{Tabel 13. Uji Coba Sistem}

\begin{tabular}{|l|l|}
\hline \multicolumn{1}{|c|}{ Data Masukkan } & \multicolumn{1}{c|}{ Poin Uji } \\
\hline \multicolumn{1}{|c|}{$\mathbf{1}$} & \multicolumn{1}{c|}{ Proses Log in } \\
\hline Log in & Melihat data berita \\
\hline Lihat Data Berita & Proses tambah data berita \\
\hline Tambah Data Berita & Menghapus data berita \\
\hline Hapus Data Berita & Mengedit data berita \\
\hline Edit Data Berita & Melihat data agenda \\
\hline Lihat Data Agenda & $\begin{array}{l}\text { Proses tambah data } \\
\text { agenda }\end{array}$ \\
\hline Tambah Data Agenda & Menghapus data agenda \\
\hline Hapus Data Agenda & Mengedit data agenda \\
\hline Edit Data Agenda & Melihat data album foto \\
\hline Lihat Data Album Foto & $\begin{array}{l}\text { Proses tambah data } \\
\text { album foto }\end{array}$ \\
\hline Tambah Data Album Foto \\
\hline Henda
\end{tabular}

Gambar 3. Entitiy Relationship Diagram

Jurnal Saintekom, Vol.7 , No.1, Maret 2017 


\begin{tabular}{|l|l|l|}
\hline $\begin{array}{l}\text { Lihat Data Download } \\
\text { Pengunjung }\end{array}$ & $\begin{array}{l}\text { Melihat data Download } \\
\text { pengunjung }\end{array}$ \\
\hline $\begin{array}{l}\text { Lihat Data Galeri Foto } \\
\text { Pengunjung }\end{array}$ & $\begin{array}{l}\text { Melihat data galeri foto } \\
\text { pengunjung }\end{array}$ \\
\hline
\end{tabular}

\section{IMPLEMENTASI}

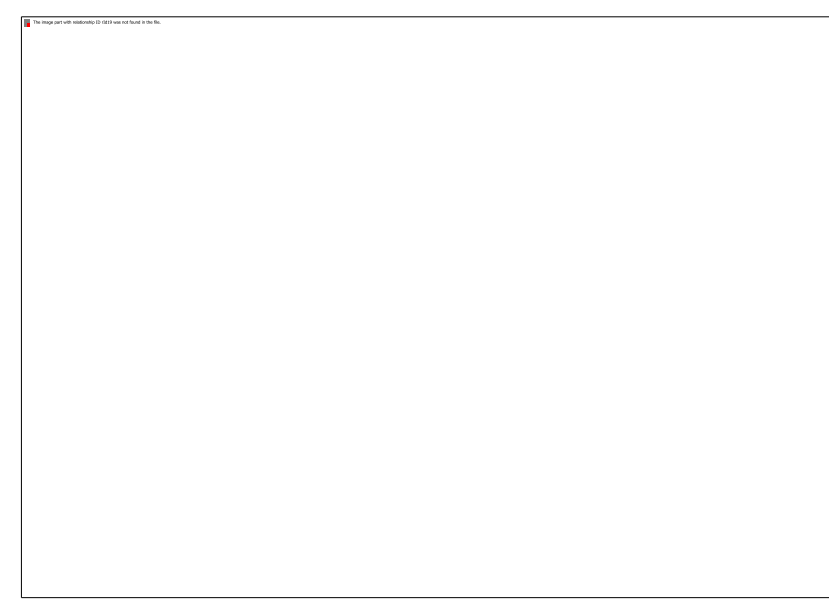

Gambar 4. Halaman Utama Sistem

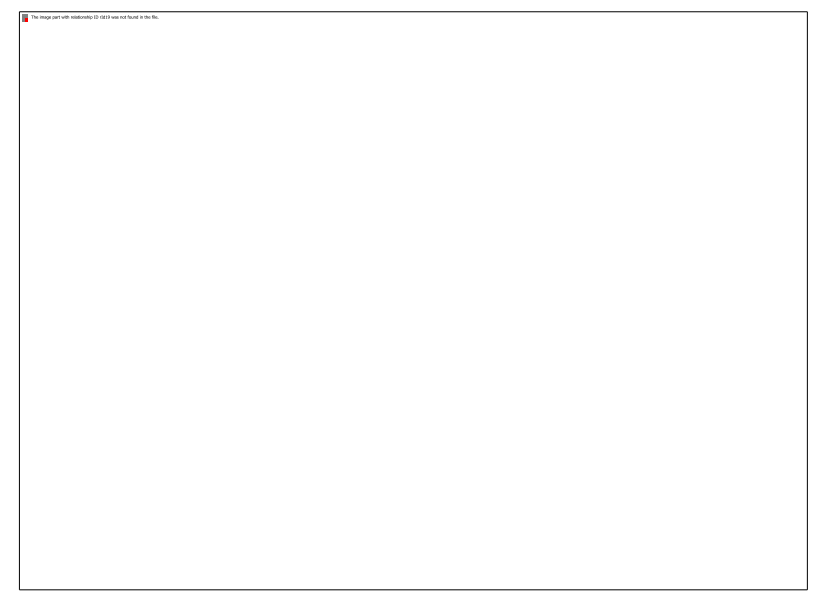

Gambar 5. Halaman Berita

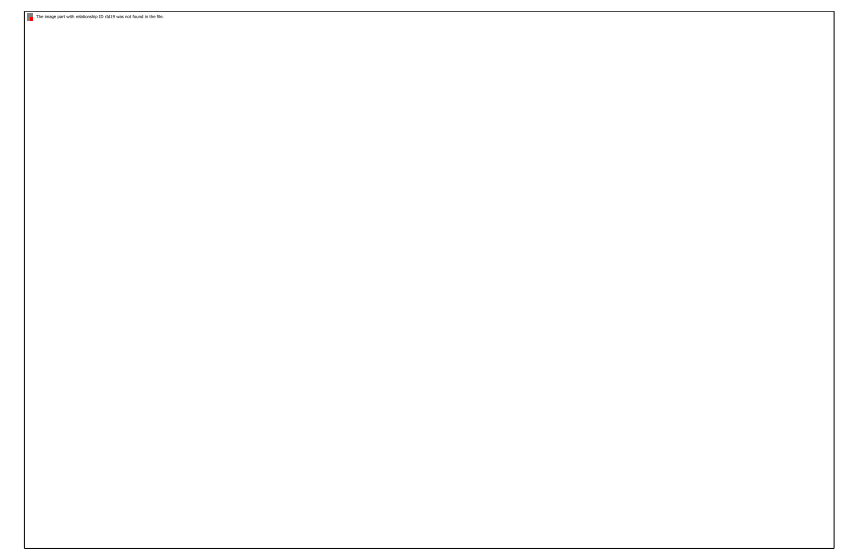

Gambar 6. Halaman Download File

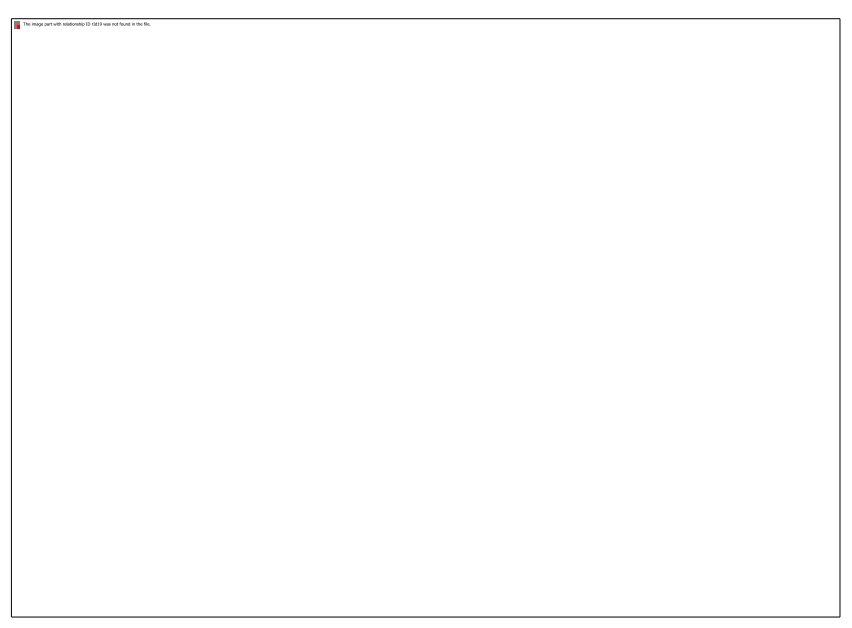

Gambar 7. Halaman Galeri Foto

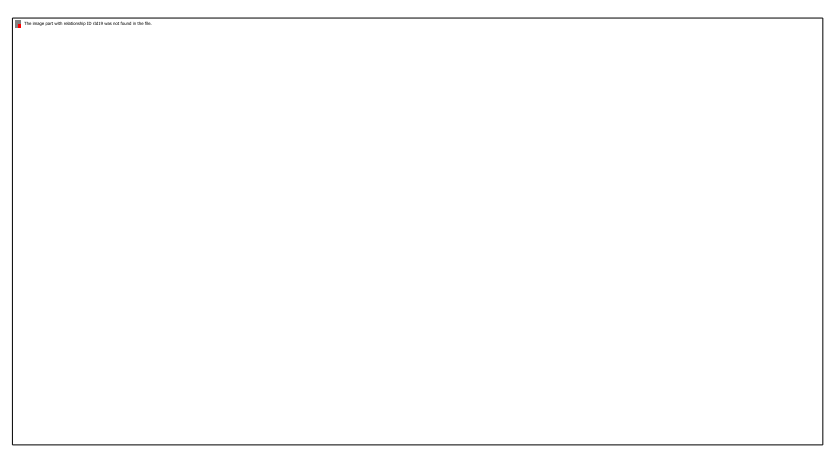

Gambar 8. Halaman Utama Administrator 
Berdasarkan analisis, perancangan dan pengujian maka dapat ditarik kesimpulan yaitu :

1. Dengan adanya website ini pengunjung dimudahkan dalam mencari informasi tentang harga komoditas perkebunan,pengumuman dan agenda Gambar 9. Halaman Penambahan Berita

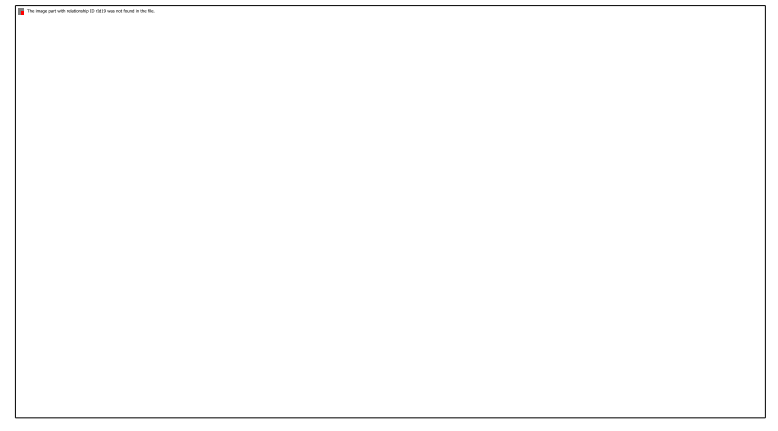

Gambar 10. Halaman Upload File Download

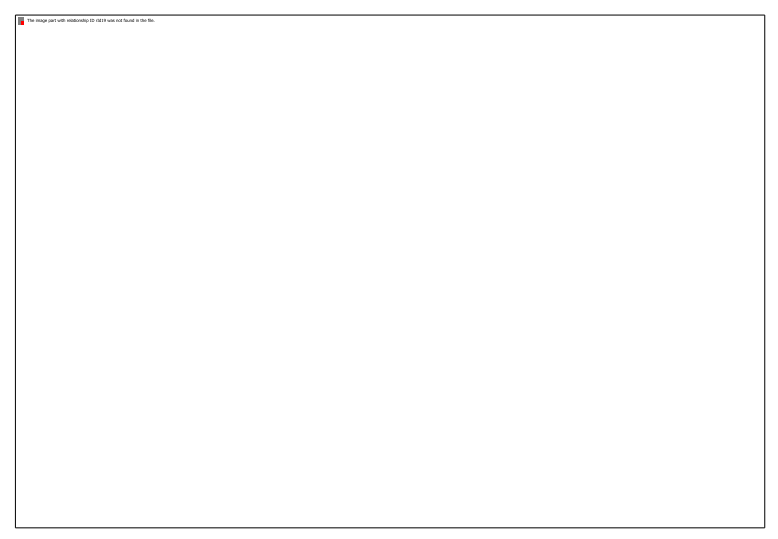

Gambar 11. Halaman Data Galeri kegiatan dinas, download file perkebunan serta dapat melihat foto dan video kegiatan Dinas Perkebunan Provinsi Kalimantan Tengah.

2. Dengan adanya website ini fitur yang dapat digunakan pengunjung lebih effisien dalam mencari informasi yang diperlukan dan fitur yang lebih banyak dari media blogspot sebelumnya, yaitu ada penambahan fitur download file , melihat agenda dan pengumuman terbaru, serta fitur yang lainnya.

\section{SARAN}

KESIMPULAN

Adapun saran yang diberikan penulis untuk kedepanya, penulis mengharapkan sebagai berikut: 
1. Diharapkan kedepannya bagi mahasiswa yang ini mengembangkan website ini dapat membuat website tersebut menjadi responsive agar dapat diakses dengan mudah menggunakan smartphone.

2. Pengembang dapat membuat fasilitas forum diskusi untuk dapat memudahkan pegawai dalam berkomunikasi antar pegawai Dinas Perkebunan Provinsi Kalimantan Tengah maupun antar pegawai Dinas Perkebunan yang ada di Indonesia.

\section{DAFTAR PUSTAKA}

Al Fatta, Hanif. 2007. Analisis dan Perancangan Sistem Informasi. Yogyakarta, ANDI.

Arief, M. 2011. Pemrograman Web Dinamis Menggunakan PHP Dan Mysql. Andi, Yogyakarta.

Basuki Pribadi A. 2014. Proyek Membangun Website Berbasis PHP dengan Codeigniter. Lokomedia, Yogyakarta.

Sudaryono, Suryo Guritno, Untung Rahardja. 2011. Theory and Application of IT Research : Metodologi
Penelitian Teknologi Informasi. Penerbit Andi, Yogyakarta.

Hakim L. 2010. Bikin Website Super Keren dengan PHP \& JQuery. Lokomedia, Yogyakarta

Kadir, A. 2008. Dasar Pemrograman Web Dinamis Menggunakan PHP. Andi, Yogyakarta.

Kadir, A. 2009. Membuat Aplikasi Web Dengan PHP dan Database MySQL. Andi Yogyakarta.

Lamato Syafri M. 2014. Perancangan Company Profile Berbasis Web Dengan Menggunakan Framework Codeigniter Di Bappeda Gorontalo, Skripsi, STMIK AMIKOM Yogyakarta

Muhajir. 2010. Sistem Informasi Berbasis Web Dinas Pertanian Pemerintahan Kabupaten Asahan Kisaran, Skripsi, Universitas Sumatra Utara.

Nugroho, A. 2010. Analisis Perancangan Sistem Informasi dengan Metodologi Berorientasi Object. Informatika. Bandung

Rio, A. 2011. Rancang Bangun Company Profile Berbasis Web ( Studi Kasus Pada Dinas Komunikasi dan Informatika Surabaya, Skripsi, STIKOM Surabaya.

Rusli. 2013. Membuat Aplikasi GPS dan Suara Antrian Dengan PHP. Lokomedia. Yogyakarta

Sholiq. 2006 . Pemodelan Sistem Informasi Berorientasi Objek dengan UML. Graha Ilmu. Yogyakarta. 
Sommerville. 2003. Software Engineering (Rekayasa Perangkat Lunak). Erlangga, Lancaster.

STMIK Palangkaraya. 2014. Pedoman Penulisan Proposal Dan Skripsi Teknik Informatika. Palangkaraya.

Tuhuteru I.P.M. 2013. Perancangan dan Analisis Sistem Informasi Pertanian Berbasis Web Menggunakan Arsitektur Model View Controller. Skripsi, Universitas Kristen Satya Wacana.

Utomo.2013. Mobile Web ProgrammingHTML5, CSS3, JQuery Mobile. Andi, Yogyakarta.

Zelmi Arizal N. 2013. Pembuatan Website Dinas Pendapatan Pengelolaan Keuangan dan Aset Kabupaten Pacitan. Skripsi, Universitas Surakarta. 